\title{
DESCRIPTIONS OF NINE NEW SPECIES OF BUPRESTIDE.
}

\section{BY EDWARD SAUNDERS, F.L.S.}

The types of these species are in the collection of the British Museum.

\section{Melobasis cupreovittata.}

Fusca; capite cupreo, piloso, fortiter ruguloso-punctato; thorace punctato, lateribus rotundatis; elytris punctatis, lateribus postice denticulatis, utrinque vittis duabus cupreis, unâ basali, alterấ apicali ornatis. Subtus cuprea, lateribus pilosis.

Head coppery. Thorax cyaneous-brown. Elytra brown; each with two longitudinal vittæ, and a spot on the lateral margin coppery-golden, of these vittæ the upper one begins at the base near the shoulder and gradually approaches the suture, reaching to just beyond the middle of the elytra; the posterior one begins just beyond the middle, but nearer the lateral margin, and does not reach the apex : the marginal spot is placed above the middle; beneath coppery-brown, centre brilliantly coppery.

Head rugosely punctured and covered with greyish hairs. Thorax, at the base, half as broad again as long; anterior margin emarginate, sides rounded, base very shallowly bisinuate; surface punctured, the punctures closer together and deeper on the sides, which are covered with grey hairs. Elytra twice as long as wide, punctured, each with four slightly raised lines, including the suture; sides denticulate near the apex, which is largely rounded. Beneath, punctured, sides and legs covered with long, adpressed, silvery-grey hairs.

Length, $6-7$ lines. Breadth, $2-2 \frac{1}{2}$ lines.

Hab. : Gawler, Australia.

\section{Melobasis costata.}

Cupreo-fusca; capite thoraceque punctatis; elytris punctatis, utrinque costis quatuor nitidis ornatis, marginibus postice denticulatis, apice utrinque spinoso. Subtus punctata, lateribus albopilosis.

Entire insect coppery-brown.

Head flat, deeply punctured; pubescent above the mouth. Thorax, at the base, three-quarters as broad again as long; anterior margin smooth, very slightly raised, and somewhat emarginate ; sides scarcely rounded behind the anterior angles; posterior angles acute; base with a shallow median lobe ; surface punctured, especially at the sides. Elytra twice as long as wide, finely and very closely punctured, each with four raised smooth lines, those on the sides less distinct than those nearer the suture; sides slightly sinuate below the shoulder, finely denticulate posteriorly, apex of each terminating in a sharp spine. Beneath punctured, sides and legs hairy.

Length, 7-8 lines. Breadth, 2-21 lines.

Hab. : Swan River. 
Differs from $M$. nervosa, Boisd., by the straighter sides to the thorax, the more strongly marked costæ of the elytra, and also by the apex of each elytron terminating in a sharp spine.

\section{Melobasis rubromarginata.}

Anea; capite punctato; thorace punctato, margine anteriori rotundatâ; elytris punctatis, lateribus cupreis, utrinque costis quatuor elevatis, marginibus posterioribus denticulatis. Subtus viridis, punctata, lateribus igneo-cupreis.

Above bronzy. Sides of thorax with a slight coppery tinge. Margins of the elytra coppery-red. Beneath green; sides of breast and abdomen coppery-red.

Head deeply and rugosely punctured, with a few scattered hairs. Thorax, at the base, two-thirds as broad again as long; anterior margin produced in the centre and at the anterior angles; sides slightly rounded; greatest width of the thorax just behind the middle ; posterior angles nearly right angles ; base shallowly sinuate ; surface punctured, very closely so on the sides. Elytra twice as long as wide, punctured, each with four raised costæ; sides sinuate below the shoulders, denticulate from behind the middle, apex of each somewhat pointed. Beneath and legs punctured, sides with a few very short white hairs.

Length, 6 lines. Breadth, $2 \frac{1}{4}$ lines.

Hab. : N. W. Australia.

\section{Melobasis igniceps.}

Aineo-fusca; capite igneo-cupreo, albopiloso; thorace punctato, lateribus rotundatis; elytris punctatis, lateribus postice denticulatis, utrinque lineis duabus elevatis irregularibus ornatis. Subtus punctata.

Head fiery-red, rugosely punctured, covered with silvery hairs. Thorax, at the base, three-quarters as long as wide; anterior margin rounded, slightly produced at the angles; sides rounded, posterior angles acute, being slightly produced towards the shoulders; base, with a largely rounded median lobe; surface punctured, especially on the sides; dorsal line indicated at the base by a large puncture; sides, each with a small ovate punctured depression just above the hinder angle. Elytra a little more than twice as long as wide, closely and rugosely punctured, each with two slightly raised vein-like lines uniting behind the middle, and not quite reaching the apex; sides sinuate above the middle, posterior margin denticulate; apex of each rounded. Beneath and legs punctured, covered with short white hairs.

Length, 7 lines. Breadth, 2 lines.

Hab.: N. W. Australia.

\section{Melobasis Leta.}

Capite thoraceque cœruleo-viridibus, punctatis; elytris viridibus, punctatis, costis quatuor cupreis utrinque ornatis, lateribus concoloribus, apicibus rotundatis. Subtus aureo-cuprea, punctata, pedibus antennisque cyaneis. 
Head and thorax bluish-green, the latter with coppery reflections. Elytra green, each with four raised lines, and the margin cupreous. Beneath copperygolden, legs and antennæ cyaneous.

Head punctured, covered with long white hairs. Thorax two-thirds wider than long at the base; anterior margin produced in the centre and at the angles; sides rounded, gradually converging to the base; widest just behind the anterior angles; base nearly straight; surface deeply punctured, especially at the sides; dorsal line faintly marked. Elytra nearly twice as long as wide, deeply punctured, each with four raised costæ; sides denticulate behind the middle, apex of each finely rounded. Beneath and legs punctured, covered with long grey hairs.

Length, 5 lines. Breadth, $1 \frac{3}{4}$ lines.

Hab.: Australia, Swan River.

N.B.-I have another specimen almost entirely coppery.

\section{Melobasis VIRIDICEPS.}

Anea; capite viridi, punctato; thorace punctato, lateribus rotundatis, basi recta; elytris punctato-striatis, interstitiis nonnihil elevatis, marginibus posticis denticulatis, apice acuta. Subtus punctata, pedibus anticis viridibus.

Bronzy; head and front legs green. Thorax with greenish reflections on the sides.

Head punctured, covered with scattered short white hairs. Thorax threequarters as long as wide: anterior margin slightly rounded in the middle and produced at the angles; sides rounded, base nearly straight; surface deeply punctured, especially on the sides; dorsal line smooth. Elytra rugosely punctatestriate, twice as long as wide; posterior margins finely denticulate; apex pointed. Beneath and legs punctured.

Length, 5 lines. Breadth, 2 lines.

Hab. : N. S. Wales.

\section{Melobasis obscura.}

Cupreo-cenea, punctata; capite capillis albis brevissimis obsito; thorace lateribus rotundatis; elytris subtititer punctatis, marginibus posterioribus denticulatis, apicibus rotundatis. Subtus viridi-purpurea, pedibus anterioribus antice viridibus.

Coppery-bronze. Beneath with green reflections, front legs green anteriorly. Head deeply punctured, covered with exceedingly short, scattered, white hairs. Thorax, at the base, three-quarters as long as wide; anterior margin rounded in the middle, and slightly produced at the angles; sides rounded, base straight; surface closely punctured and transversely rugose, punctuation larger on the sides. Elytra slightly wider than the thorax at their base, one and three-quarters longer than wide, rugosely punctured, with two faintly raised irregular lines on each; sides sinuate below the shoulders; posterior margins denticulate; apices rounded. Beneath and legs punctured; sides with a few scattered silvery-white hairs.

Length 5 lines. Breadth, 2 lines.

Hab. : Adelaide. 


\section{MeLOBasis viridis.}

Viridis; capite thoraceque punctatis; thoracis lateribus post medium rotundatis; elytris punctatis, lateribus postice denticulatis, apice utrinque rotundatâ. Subtus punctata.

Bright green, suture posteriorly very finely margined with purple.

Head flat in front, deeply and closely punctured. Thorax, at the base, threequarters as wide again as long; anterior margin rounded, slightly produced at the angles; sides rounded, their greatest divergence being just behind the middle; base straight; surface closely and transversely punctured, especially on the sides. Elytra twice as long as wide, deeply and closely punctured, each with two very faint raised lines on the disc; sides slightly sinuate above the middle, finely denticulate posteriorly; apex rounded. Beneath and legs deeply punctured.

Length, $4 \frac{1}{2}$ lines. Breadth, 2 lines.

Hab. : Adelaide.

Note.-I have one specimen in which the elytra are of a goldencoppery hue.

Spencer Park, Wandsworth : 30 th October, 1876.

\section{NOTES ON BRITISH TORTRICES.}

BY CHAS. G. BARRETT.

(continued from vol. xii, page 8.)

Stigmonota dorsana, Fab., and orobana, Tr.

My former notes on these species (E. M. M., x, p. 148) were written from insufficient information; for instance, Orobus niger, as pointed out by Dr. F. Buchanan White, is a rare Highland vetch, and could not be the food-plant of a species found in the North of England.

For some years past, my friends Mr. J. Sang of Darlington, and the late Mr. T. Wilkinson of Scarborough, endeavoured to work out the life-histories of these two species, with, until the past season, but partial success.

Orobana appears to be exceedingly local, and is found on the cliffs to the north of Scarborough, among Vicia sylvatica, over which plant it flies commonly on sunny afternoons in July. It has also repeatedly been reared from larvæ in the pods of that plant. Mr. Sang thus describes the larva:- "When full-fed, dark yellow, with a decided brown tinge; head and second segment nearly black; spots prominent. When younger, some are lighter yellow, with the spots distinct but not so prominent." Full-fed early in September, when it leaves the seeds and spins a tough cocoon among rubbish.

I reared this species myself last July from pods of Vicia sylvatica received from Mr. Wilkinson: 


\section{$2 \mathrm{BHL}$ Biodiversity Heritage Library}

Saunders, Edward. 1876. "Descriptions of nine new species of Buprestidae." The Entomologist's monthly magazine 13, 155-158.

https://doi.org/10.5962/bhl.part.22821.

View This Item Online: https://www.biodiversitylibrary.org/item/35879

DOI: https://doi.org/10.5962/bhl.part.22821

Permalink: https://www.biodiversitylibrary.org/partpdf/22821

\section{Holding Institution}

Smithsonian Libraries

\section{Sponsored by}

Smithsonian

\section{Copyright \& Reuse}

Copyright Status: NOT_IN_COPYRIGHT

This document was created from content at the Biodiversity Heritage Library, the world's largest open access digital library for biodiversity literature and archives. Visit BHL at https://www.biodiversitylibrary.org. 